\title{
Out-migrants and Local Institutions: Case Study of a Depopulated Mountain Village in Japan
}

\author{
Mika Okubo $^{1,2}$, Abrar Juhar Mohammed ${ }^{2} \&$ Makoto Inoue $^{2}$ \\ ${ }^{1}$ Lake Biwa Museum, Shiga, Japan \\ ${ }^{2}$ Graduate Shool of Agricultural and Life Sciences, University of Tokyo, Tokyo, Japan \\ Correspondence: Mika Okubo, Lake Biwa Museum, Shiga, 525-0001, Japan. Tel: 81-77-568-4811. E-mail: \\ okubo@lbm.go.jp
}

Received: July 6, 2015 Accepted: July 17, 2015 Online Published: July 23, 2015

doi:10.5539/ach.v8n1p1 URL: http://dx.doi.org/10.5539/ach.v8n1p1

\begin{abstract}
Rural depopulation is now well acknowledged to be one of the salient challenges faced by Japan (Ohno, 2005; Odagiri, 2006). However, out-migrants that left their village of origin still maintain their bond with the villages through local institutions and natural resources. By taking Mogura village in Hayakawa town, Yamanashi prefecture as a case study, this article discusses relationships between out-migrants and their depopulated village of origin by focusing on local institutions and natural resource management. Data was collected using open ended interview and participant observation methods. The result shows that, although the style of observing has changed, out-migrants play important role in local institutions and assisting resource management of their depopulated village of origin. The institutions still have meaning for out-migrants to keep relationships with their village of origin. Several customs, such as collaborative labor, obon, New Year vacation, and the anniversary of ancestors' death ceremony, provide scheduled opportunities for out-migrants and residents to get together and good reasons to come to the place of the village of origin. We argue that local institutions and natural resources, although in the process of transformation, can be helpful tools to link out-migrants with villages. We, however, take precaution on whether such role will be transferred to next generation of the out-migrants that are born and are living outside the village of origin of the out-migrants.
\end{abstract}

Keywords: mountain village, out-migrants, rural depopulation, rural out-migration

\section{Introduction}

The Japanese population has been almost flat since the 2000s, and it is forecasted to decrease (Somusho, 2012). The population aging rate (the percentage of people over 65 years old) has been growing so rapidly that it took only 24 years to go from $7 \%$ to $14 \%$, compared to France (took 126 years to go from 7\% to 14\%), Sweden (85 years), Germany (40 years) and England (46 years) (Naikakufu, 2014). Shrinkage in the population is an important issue in contemporary Japan (Matanle, 2010).

Urban migration of the young generation that has increased since the economic boom in late 1950s is considered to be a major reason for the rural depopulation. The Mountain Village Development Act was enacted in 1965 and the Act on Emergency Measures concerning Development of Depopulated Areas was enacted in 1970 to alleviate the situation. Despite these efforts, the problem persisted. After the rural to urban outmigration of younger generations, older generations continue to live in rural villages. In recent years, however, this generation become aged, and in some cases, has passed away, causing many problems (Odagiri, 2006). Ohno (1991) labeled communities with elderly population (over 65 years) over 50\% as 'Genkai-shuraku' ('boundary community'). Among the major problem faced due to depopulation and aging includes desolation of fields and forests (Ohno, 2005; Odagiri, 2006), the difficulties in preserving cultural heritage (Hoshino, 2009), and loss of pride in the community (Odagiri, 2006). Out-migrants, people who have lived at rural area and who are presently based outside the area, have been perceived to be 'people who abandon their origin home and village' (Tokuno, 2008). However, existing research has established that some out-migrants, if their parent still lives in the rural village, visit and help their parents constantly (Araki, 1994; Tachibana et al., 1998; Ashida 2006; Ishizaka, 2002; Ishizaka \& Midorikawa, 2005; Tokuno, 2008). Even after their parents die, out-migrants continue to visit and relate with their village of origin. (Okubo et al., 2011).This article expands the aforementioned argument by focusing on out-migrants role in maintaining local institution and natural resource management. 
The remainder of the paper is organized as follows: the next section provides a briefly describes local institutions in Japan in general and research site in particular. The method section elaborates the research site and data collection method. In the result and discussion parts, history of out-migration is presented followed by analysis of out-migrants participation in local institution and natural resource management. Finally, the conclusion section presents key findings and suggestions for future research.

\section{Local Institutions}

Community association, shrine parishioner and temple parishioner are typical and major institution of Japanese rural community. However, there are also other local institutions such as Dozoku, and Oyabun-kobun in the research site. This section will briefly introduce the structure and function of these institutions.

\subsection{Community Association}

An organized cluster of approximately 20-30 houses is called a mura (community) in Japanese rural sociology. The origin of mura was naturally generated by the people living in the place because of their daily demands. At the same time, the mura was used as a unit of control. In the centralized feudalism in the Edo era, the area of administration unit overlapped with the mura. After the Meiji era, the government promoted municipal merge and hence, the administration units became larger and larger. However, the area unit and community of mura still have important meanings in daily life (Torigoe, 1993).

Each mura has its own community association. In Japanese rural communities, the members of community associations are not individuals but ie (household) (Torigoe, 1994:6). In the rural community, each household fulfills its duty as a community member by bearing costs and providing labor for the village, and each household enjoys the right to benefit from communal resources such as common land (Aruga, 1970:80-81). The unit of right to benefit from common land or common forest is called $k a b u$, and each household that is acknowledged as the member of the community can have one kabu each (Suzuki, 1968: 166). The next generation of every household that has membership in the local community inherits the community forest usufruct rights, water rights and the rights to participate in the operation of the community association (Nakagome, 1999).

\subsection{Shrine}

Shrines can be divided into two types in general (Sonoda, 1999a, 1999b). One is the Sukeishin type, in which the power of the god is emphasized, and this type of shrine is visited by people extending beyond the local community. The other is the Ujigami type, which is enshrined by the specific local community, and the god blesses the specific area and its community members. The residents of the specific local community are called Ujiko (Shrine parishioner) and have rights and duties of holding festivals of the shrine (Sonoda, 1999a). Ujigami has abstract faith for productiveness of grain (Gokoku-hōjō) or family safety (Kanai-anzen), compared to other specific faiths, to avert fire or thunder. The faith in Ujigami is recollected on the occasion of the festival and during community crises, such as droughts or harvest failures (Kamitani, 1983). Spring festivals for wishing for a good harvest and autumn festivals for expressing gratitude for harvests are annual events and the Ujiko celebrate them (Uranishi, 1987).

\subsection{Temple}

Ancestor worship is a feature of ie (Japanese family) (Torigoe, 1993). It is believed that Buddhism and Japanese indigenous religion mixed and became the Japanese style Buddhism combined with ancestor worship (Hoshino, 1983). Each village has one or few temples and households belong to a temple (Matsuzaki, 1989). The household belongs to temple called danka, and danka have its association. When bon, higan and anniversary of ancestors' death, danka households visit temples or invite a Buddhist monk of the temple to their house (Fujii, 1999) as well as visiting ancestors' graves.

Bon and Higan are annual events for memorial service for deceased family members or ancestors and are popular opportunities for visiting ancestors' graves (Komatsu, 1999a). It is believed that during the bon period, ancestors come back to this world and stay home together with family members (Hoshino, 1983). People make a special shelf and put vegetables and fruits there, and take ancestors' spirits to and from the shelf (Hoshino, 1983).The anniversary of ancestors' deaths is also an opportunity for visiting ancestors' graves. At the $1^{\text {st }}, 3^{\text {rd }}, 7^{\text {th }}, 13^{\text {th }}$ and 33th anniversary, a ceremony is held in which family and relatives get together and Buddhist monks chant Buddhist sutras for the ancestor (Hoshino, 1983; Komatsu, 1999b).

\subsection{Other Local Institutions}

In Japanese society, there are two types of Shinzoku (kin) (Torigoe, 1993). One is called dozoku, and the other is called shinrui in Japanese rural sociology (Torigoe, 1993). Dozoku is ancestor-based group, compared with 
shinrui, which is ego-based. Dozoku is a type of descent group, defined as 'cohesion of household (ie) that consists of its original family (honke) and the branch family (Bunke)' (Torigoe, 1993).

Another local institution is Oyabun-kobun. Oyabun-kobun is a traditional institution that makes personal relationships between a pseudo parent and child. The Oyabun-kobun relation does not need to change the consanguineous parent and child relation, and it adds a new relation to the original consanguineous family (Torigoe, 1993). The Oyabun (pseudo parent) protect their kobun (pseudo child), and sometimes demand some service instead (Torigoe, 1993).

\section{Methods}

\subsection{Description of the Research Site}

This research adopted a case study approach and examined local institutions and how out-migrants relate to the institutions. The research site is Mogura village in Hayakawa town, Yamanashi prefecture, Japan. Yamanashi prefecture is located almost at the center of Honshu Island. The prefectural capital and other city administrations are located in Kofu basin at the center of the Prefecture. The prefecture is surrounded by mountains, including mountains of over 3000 meters, and these areas are mainly rural. Hayakawa town is located in the mountain area and the entire town of Hayakawa town is subject to both the Mountain Village Development Act and the Act on Special Measures Concerning Promotion of Self-Reliance in Depopulated Area. Mogura Village is located in the middle of a mountain path in the mountain area at an altitude of approximately $900 \mathrm{~m}$. It is about $60 \mathrm{~km}$ from the prefectural capital.

Mogura village takes 1 hour to walk to the nearest bus stop. So a private car is an important method of transportation. Those who cannot drive ask their spouses, children or relatives to drive. There was a small general shop in the village, but it was closed in 2012. Most residents who can drive car use a supermarket located at approximately one hour drive from the village. Two mobile sellers come to the village every week. Regarding medical facilities, the villagers can use a temporary clinic in a nearby village twice a month, and there is a general hospital approximately one hour from the village by car.

\subsection{Data Collection Methods}

The data collection was conducted as follows. The field studies were conducted between 2008 and 2014 using the Japanese language. Two main data collection method employed are participant observation and open-ended interviews. The first author stayed in Hayakawa town for a total of 246 days, and observed participation of residence and out-migrants in different activities. In addition, open ended interview was conducted for a total of 34 residents, 38 out-migrants, 6 out-migrant spouses and 17 out-migrants' children. Some people spend approximately half a week in Mogura, and it is difficult to ascertain whether they are residents or out-migrants. Therefore, based on the residents' perceptions, this research considered 37 people from the total of 23 households at the site to be residents

\section{Results and Discussion}

\subsection{History of Out-Migration and Current Condition in Mogura Village}

The villagers used to practice slash and burn cultivation until soon after the end of the Pacific War. They then cultivated wheat, buckwheat and millet. Because of its precipitous geographical conditions, villagers could not cultivate wet rice in the village. Only a few households had paddy fields near the village and cultivated rice. Most households wished to eat white rice as usual, and almost 20 households bought rice paddy fields in the Kofu basin approximately 1950. Mogura mine is located near the village, so many villagers worked at the mine and earned cash income. Working in forestry, in construction, at the town office, at the post office or at the hydro power plant were other means of earning income for the households

In the late 1960s, it became common for children to enter high school after finishing their junior high school. In 1965 , however, the only high school close to the village was closed. As a result, there was no other choice but to out-migrate to the Kofu basin from the village to live close to and attend high school. Some households already had their paddy field in Kofu basin and a small lodge for their agricultural work. These households renovated the lodge, and it became the house for their sons or daughters living in Kofu basin. Mogura-mine was closed in 1968. This was also a trigger stimulating out-migration. Some villagers out-migrated to the Kofu basin or other areas to obtain jobs.

In 2009, the number of households at the research site was 23 with a population of 37 out of whom 33 were over 65 years old. The number of people living alone was 9 , almost $40 \%$ of the number of households. Most villagers lived on pensions and self-sufficient agriculture. Of the residential households, 19 had places where they could stay outside of Mogura, such as with their children (the situation was unclear for the other four households). Some 
residents were based outside Mogura for approximately half a week, while others were considering moving to live with their children outside the area.

According to the results of the questionnaire survey, 24 of the 26 out-migrants migrated within Yamanashi Prefecture. 9 of the 24 out-migrants migrated to Showa town because many household bought lands for paddy fields approximately in 1950 in this area. They built their new house on the land afterward. Now Showa town is a convenient area that has many residential streets, two industrial complexes, many chain stores, and a highway ramp. The out-migrants in Yamanashi prefecture lived within 45 minutes to 100 minutes by car from the research site.

\subsection{Out-Migrants Participation in Local Institutions}

\subsubsection{Out-Migrants as Members of a Community Association}

The research site's community association is called $K u$. In 2009, 63 households joined the community association. Among these, 40 households have already out-migrated, and no household member lives in the village, but they are still members of the community association. The community association addresses any issues that are related to the overall community and also manage the water system and community center.

The association is mainly run by its board members. The most important of these positions are those of chief, sub-chief, and proxy-chief. Once someone becomes proxy-chief, he becomes sub-chief in the next year and chief in the following year. These posts are served by residents. The chiefs must take measures when there are accidents, such as typhoons or heavy snow. Therefore, it is necessary for the chiefs to stay in the village on a daily basis.

These posts are always served by a man but there are many unwritten jobs for their wife. Most out-migrants who spent their period of youth outside the village got married to people who are from outside the village. If out-migrants become a chief, it is sometimes difficult to obtain support from their spouses. After 2000, no younger people served as a chief for the first time, and hence the position of chief has been taken repeatedly by available residents. Moreover, the proxy chief election became difficult because the pool of possible candidates decreased. So, now the proxy chief is decided by negotiation with the former chief.Council members play an ancillary role to these three positions and are asked by the chief to attend gatherings or provide assistance. At present, out-migrants are considered to be able to serve as council members, which some of them do.

Even if they do not serve any posts, each household including out-migrated households have duties as a community association member. Each household has to pay 5000 yen per year as a membership fee. At least one household member has to attend community collective work days (Soninsoku) twice a year and the annual general meeting (Sokai) once a year. In the case of out-migrated households, a particular person such as an eldest son or a family member who out-migrated relatively close to the village is the main participants in the collaborative labor and annual general meeting. It is no problem if family members other than the main member participate in the events. The schedule of the collective work days and annual general meeting do not change every year, and people can obtain the schedule at the annual general meeting. Therefore, out-migrants also know the schedule in advance.

In the collective work days, the work starts after a short speech by the chief. The speech always starts with 'Thank you very much for coming and gathering from a long distance away.' Participants do tasks such as cleaning roads and checking water sources and fire hydrants. Older participants are given less physically strenuous tasks such as cutting grass around the community center. Most of the participants participate in the cleanup of the road. The road is approximately $4 \mathrm{~km}$ long; participants are divided into 4 groups and remove rocks and fallen leaves on the road and in the drainage ditch. The residents and out-migrants work together for approximately 3 hours. For out-migrants, the road holds many memories because when they were child they walked almost every day to attend school. During the work, the participants enjoy talking about memories of their childhood. Out-migrants' children sometimes also attend and work together.

The annual general meeting is a place of sharing, where residents and out-migrants can discuss their views on the current situation in the community. In the meeting, the board members reported and approve financial report, budget, and board members for the new financial year. There is also discussion regarding what items should be discussed and recognized by the overall community.

After the collective work days and the annual general meeting, they usually have a small party with some dishes and alcohol, sometimes barbeque. When the residents are able to obtain bush meat, they cook the venison or wild boar meat for the participants of the collective work. Eating and drinking, they talk about recent events and fond memories. For example, memory of a grand-grandfather of an out-migrant was discussed by a young out-migrant and an elderly resident (29 $9^{\text {th }}$ April 2011). 


\subsubsection{Out-Migrants as Shrine Parishioner}

In Mogura village, there is Kunitama shrine and the villagers are parishioners of the shrine. Shinto priest (Kan-nushi) does not reside in the village and comes only on the occasion of festivals. The parishioners keep the shrine clean and hold festivals with the leadership of parishioner representative. The representatives serve three fixed number, three-year terms. Out-migrants also serve as parishioner representatives.

There are several events related to shrine parishioners. These events used to be held by the young people's group, which was constituted by young men aged between 15 years and 25 years living in the village. After the young people's out-migration from the late 1960s, the out-migrants organized the festival. When there were events, out-migrants came back to the village and joined to conduct the events (Oikawa, 2007). Under the situation, out-migrants continued to be members of the young people's group even after they became 25 years old. The young people's group was succeeded by the preservation association approximately 1998, and the preservation association was disbanded in 2005 (Okubo et al., 2011). Subsequently, the shrine parishioner representatives assumed the main role of managing festivals (Okubo et al., 2011). The shrine representatives prepare and hold festivals with the support of three chiefs and the board members of the community association. Residents and out-migrants other than parishioner representatives and board members also help to hold festivals and enjoy festivals. Spring, summer, and autumn festivals are always held in the shrine precinct, and the shishimai (lion dance) are always held in front of the stone statue of the guardian god.

Sumo in summer festival and Mikoshi (carrying portable shrine) during the spring festival were large events that required youth power. After the disbanding of the preservation association, Sumo and Mikoshi were performed as children's versions for out-migrants' children. However, the children's version of Sumo and Mikoshi have not been enacted since 2013. Instead residents and out-migrants offer a bottle of sake to the shrine and hold small party at the shrine on the day.

There is also a traditional performing art called Sanbaso. According to legend, it started in the late Edo period, brought from Kurobera village within Yamanashi Prefecture (Oikawa, 2007). Sanbaso requires nine performers in total: three actors, Japanese fife, drummers, wooden clappers, and three Japanese hand drummers. In 2009, all nine of these performers were residents in their 70 s or older. This used to be handed down from young male to young male. However, this became difficult after the out-migration of young people (Oikawa, 2007). It requires to know some technique to become a performer but most out-migrants do not know these techniques. Although the fife is essential for Sanbaso, at present only two residents (both males in their 70s and 80s) can play. In other words, there is no younger inheritor of this activity.

\subsubsection{Out-Migrants as Temple Parishioners}

There are two temples in the research site, the Soto-sect of Buddhism and the Nichiren-sect of Buddhism. Each household belongs to one of them. The household that belongs to atemple is called the temple's danka. There is a danka association for each temple. Each temple has some annual ceremonies and it is managed by the danka association. Out-migrants also serve as representatives of danka assosiations and managed annual ceremonies.Buddhist monks formerly lived in the village or near the village. Now, however, they come to the village only for ceremonies. Each danka association has three fixed-term representatives. Out-migrants also fulfill the position of representatives.

There is a communal grave site in the village. In addition, each household has its family grave with a stone pagoda and holds a service for their dead family members and ancestors. One resident (female, in her 70s) said that 'I sometimes feel that my departed husband is still here. (Though I'm living alone in this house) I feel I'm not living by myself. I say thank you to ancestors every day in front of the family Buddhist altar.'

When someone in the family, even an out-migrant, dies, the cremains are laid to rest in the family grave in the village. Visiting graves and holding a service for their dead family members and ancestors is an important reason for out-migrants and also their families who have never lived in the village to come to the village.

Not only village residents, but also out-migrants believe that they want to be buried in the village grave when they die. For out-migrants to be laid to rest in the village, it is important to consider whether their children who did not spend their childhood in the village will visit their grave in the village or not. Actually, an out-migrated husband and a wife asked their eldest son $\left(2^{\text {nd }}\right.$ generation of out-migration $)$, 'Please continue to visit the grave at least.' The eldest son visits the grave at bon and spends bon period with his family in the village. However, a few out-migrated families have already moved the grave to other areas.

Bon period is one of the important opportunities for visiting graves in the village. When the bon period starts, members of each household visit the graves and take the ancestors' spirit to their house in the village. They put 
flowers on the graves, traditionally including wild flowers picked up from nearby hilly areas. After the bon period, they visit the grave again and take the ancestors' spirit back. Many out-migrants also visit and stay in the village with their spouses and children during the bon period. Some out-migrants do not spend bon period in the village because there is no available house to stay. They, nonetheless, still visit the grave in the village and take the ancestors' spirit to and from their house in their residence city.

During the bon period, people visit each other's houses to offer incense sticks and put their hands together before the shelves of relatives' or neighbors' families. For households that have a family member's death within one year, the first bon period (Niibon in Japanese) for the dead is special. Such households hang lanterns at the entrance of their house and welcome relatives and friends of the dead. The relatives and friends visit the house, offer incense sticks and put their hands together before the shelf made for bon. After that, the bereaved serve tea and snacks and talk to the visitors. Even when out-migrants die, the bereaved family spends the first bon period at the village house or sometimes prepare to welcome relatives and friends both at the house in the village and in the city to which they have migrated.

The anniversary of ancestors' death ceremony also provides opportunities for residents and out-migrants to get together. The Buddhist ceremony is held in the family house in the village with a Buddhist priest. After the ceremony, the attendants are formerly invited to a meal at the host's house. These days, it is common to be invited to a meal at a restaurant near the village.

\subsubsection{Out-Migrants and Dozoku}

At the research site, the local name of dozoku is maki. There are only 7 family maki in the research site. Households $(I e)$ that have the same family names are in the same maki. It is considered that members of the same maki should help each other when a death occurs. Funeral ceremonies used to be held in the village, but now it is common for funerals to be held at a funeral hall outside the village.

Each maki worships its ancestor and has a stone pagoda or shrine. Each maki has a day of annual festival for ancestor worship and used to get together and eat a feast at the house of the maki member household whose turn it is to host the feast. In most of the maki, the ancestors' festival has been put on hold. The maki which has the greatest number of households still continues the ancestors' festival. The members of this maki worship their ancestors at a shrine called yama-no-kami (god of mountain). The annual ancestors' festival is held on the weekend nearest the harvest moon. The maki household members get together, cut the grass and weeds around the shrine, and have snacks and drink sake before the shrine. In 2009, 14 people ( 8 residents, 3 out-migrants, 1 out-migrant's wife, 1 out-migrant's child and 1 cousin) participated in the festival. There were out-migrants that had responsibility for hosting.

\subsubsection{Out-Migrants and Oyabun-Kobun}

At the research site, there is a particular oyabun-kobun institution called nazukeoya (godparent). All children who were born and raised in the village had godparents. The godparents were invited to each rite of passage of the godchild and gave gifts to them. The godparents sometimes bought school bags for the godchild when he/she entered school. As for the godchildren, they came to the funeral ceremony of the relatives of the godparent and offered more condolence money than others.

The function of the oyabun-kobun institution is considered to be 'strengthening ties in the village'. Villagers explained the institution as follows.

'Oyabun-kobun is an institution to increase the number of relatives as blood ties became weaker with each succeeding generation. The more relatives within the village, the more helpful it is. If something happen, we can help each other.' (male, 80 s, resident)

'As cousins died and only second cousins are left, I guess people decided to ask them to become godparents in order to preserve relationship.' (male, $80 \mathrm{~s}$, resident)

Out-migrants' children who were born and raised in the place of immigration sometimes also have godparents. The situation differs from family to family. In a number of cases, only the eldest child or eldest son of the out-migrant had godparents. This might show that the out-migrants are conscious of who will be the heirs in the next generation. There are also cases where out-migrants became godparents of the child of other out-migrants, and it is evident that the godparent system has an aspect of enhancing ties between out-migrants.

However, the meaning of the institution has changed. Some out-migrant's children know his/her godparents well and have communication during bon period or during other opportunities. Others, on the other hand, do not know their godparents well and are not really aware of them. Different people than before are asked to become a godparent. An out-migrant explained that; 
'In the old days we used to ask people with distant relationship to be godparents. But nowadays, we ask people to whom it is easy to ask.' (male, $40 \mathrm{~s}$, out-migrant)

This shows that the institution changed from a necessary one that strengthens ties in the village to a merely formal one.

\subsection{Out-Migrants Role in Natural Resources Management}

\subsubsection{Forest}

Around 1950 the villagers planted Japanese cedar (Cryptomeria japonica) or Japanese cypress (Chamaecyparis obtusa) after slash and burn farming. This plantation forest was the reason for visiting the village by two of the out-migrants. As the forest hasn't been managed for a long period, even property lines within the forest became indistinct. One of the villagers explained the situation as follows;

'I cannot distinguish where our family's forest starts and ends. For my son, it is more difficult to distinguish the boundary. I want to prune trees, but I cannot.' (male 80s, resident)

Hence, without connecting the out-migrant with the villagers, the future of the local forest seems dim. The motivation shown by some of the out-migrants to visit the village because of the forest, hence, is indispensable.

\subsubsection{Farmlands and Vegetables}

Residents cultivate vegetables, buckwheat, millet and corn in their field. This was mentioned as a main reason for six of the interviewed out-migrants visiting the village. Local vegetables are enjoyment to visit village for out-migrants. Agricultural work is mainly by residents. Out-migrants contrive easy way to manage their field.

There are, however, out-migrants who cultivate their own field even though their parents do not live in the village. One of them (out-migrant in his 60s) started to cultivate after his retirement. He visits the village once every $1-2$ weeks. Another person (out-migrant in his 60s) cultivates vegetables. In the latter case, he gets assistance from his elder sister for planting, harvesting as well as daily care.

The villagers cultivate some indigenous varieties using their own seed production. In particular, a variety of gourd (Cucumis spp.) called mogura-uri is famous for its juicy taste. The residents and out-migrants think that when the gourd is cultivated in other areas the taste changes so it can be cultivated only in the village. They pay attention not to cross it with other varieties.

In some cases, they plant Japanese butterbur (Petasites japonicas) or bracken (Pteridium aquilinum), and perennial wild vegetables. The shoots and buds of the Japanese butterbur and the shoots of the bracken are edible and have a distinctive fresh flavor. They usually grow wild, but the villagers pick the seedlings from nearby forests and plant in the unutilized field. Once the seedlings are planted, they provide their shoots every spring without daily management. Villagers including out-migrants picked the shoots and buds and enjoyed them as spring mountain delicacies.

\subsubsection{Beekeeping}

At least 6 residents and 2 out-migrants practice beekeeping. They consider the honey collected in the village to have better taste than honey collected at the lower altitude areas. They exchange their information and techniques such as how they protect the bees from animals when bees have left the old nest and how to capture them and induce them to build new nest in beehives. One beekeeper (resident in his 70s) said, 'I'm happy when the bees get together where I expected.' They enjoy beekeeping, and beekeeping provides a common enthusiastic topic for their daily conversation.

\subsubsection{Wild Animals Meat}

There are residents and out-migrants who also do hunting. One out-migrant (male, in his 60s) said that he has enjoyed hunting as his hobby until now. There are traps managed by residents at the research site and sometimes deer and boar are caught. When they get the meat of deers and boars, the meat are distributed not only to residents but also to out-migrants. Residents take the meat to out-migrants' houses in passing. If the out-migrant is not available, they -keep the meat in the freezer in out-migrants' houses. The meat is cooked and eaten during gatherings on annual collective work days or other events.

\section{Conclusion}

This article discussed out-migrants participation in local institutions and natural resource management in a mountain village of Japan. Local institutions and natural resource were found to play important roles in linking out-migrants with their village of origin as well as each other. Although the style of observing local practices has changed, the institutions still serve as a link for out-migrants to keep relationships with their village of origin. 
These practices create annual opportunities for face-to-face communication even though the people now live apart. Customs such as collaborative labor, obon, New Year vacation, and ceremonies on the anniversary of ancestors' deaths provide scheduled opportunities for out-migrants and residents to get together in the village. These events are meaningful for out-migrants to come back to the village at the same time and act together enhancing face-to-face communication on a regular basis not only with their family members but also other community members.

Some institutions are significant to connect and strengthen ties to village itself. These institutions provide a kind of format for out-migrants to participate in. Out-migrants continue to follow the customs of each institution to keep connected to the village, villagers, and out-migrants. These institutions persist even under conditions of serious depopulation as they are intricately related to core values of the villages such as religion as well as because they are space-specific. For example, it is sometimes difficult for out-migrants to move ancestors' graves from the village. Hence, relationships with the village and responsibilities as members of the community association and other institutions are important for out-migrants to maintain and visit their family graves.

There, however, remains an important concern. Currently, it is the Out-migrants who had spent their childhoods in the mountain village that are connected to the villages. However, the next generation, the children of these out-migrants, are born and raised in town and they have never lived in the village. Hence, the continuity of the linkage between out-migrants and their village with next generation is questionable. This demands further research.

\section{Acknowledgements}

This work was supported by the JSPS [grant number 26760016].

\section{References}

Ashida, T. (2006). Tashutsu-sitei no furusato eno kanyo jittai to chiiki nogyo iji ni hatasu yakuwari: Kitakanto chusankanchiiki nouson wo taisho to shite [One case of how people come to their rural home village and assist farming there : A case study of a Kitakanto rural village]. Nosonkeikaku gakkai shi [Journal of Rural Planning Association] (in Japanese), 25, 473-478. http://doi.org/10.2750/arp.25.473

Araki, K. (1994). Shumatsu nomin no jittai to tenbo: Hiroshima kencho shokuin ni taisuru anketo kekka kara [The Actual Condition and the Review of Weekend Farmer from the Questionnairing at Hiroshima Prefectural Office], Chirikagaku [Geographical sciences] (in Japanese), 49(2), 85-94.

Aruga, K. (1970). Aruga Kizaemon chosakushūIX [Aruga Kizaemon collection IX] (in Japanese). Tokyo: Miraisha.

Fujii, M. (1999). Danka [Danka]. In A. Fukuda et al. (eds), Nihon minzoku daijiten ge [Dictionary of Japanese folklore Volume 2] (in Japanese, pp. 69-70).Tokyo: Yoshikawakōbunkan.

Hoshino, H. (1983). Tera to Hotoke [Temples and Buddhist]. In A. Fukuda \& N. Miyata (eds.), Nihon minzokugaku gairon [Introduction to Japanese Folklore] (in Japanese, pp. 203-212). Tokyo: Yoshikawakōbunkan.

Hoshino, H. (2009). Mura no dentō geinō ga abunai Endangered traditional performing arts in villages] (in Japanese). Tokyo: Iwatashoin.

Ishizaka T. (2002). Setouchi kaso chiiki no koreisha seikatsu to tashutsu kazoku, Hiroshima ken kaso sanson no chosa jirei yori [Lives of the Aged and Living-Apart Families in the Setouchi Underpopulated Area]. Jinbunrongyo [Bulletin of the Faculty of Humanities and Social Sciences] (in Japanese), 19, 31-44.

Ishizaka, T., \& Midorikawa, N. (2005). Kaso chiiki no koreisha to tashutsu shi: Mie ken kii nagashima cho no chosa jirei wo toshite [The Aged and 'Living-Apart Children' in the Underpopulated Area]. Jinbunrongyo [Bulletin of the Faculty of Humanities and Social Sciences] (in Japanese), 22, 111-128.

Kamitani, T. (1983). Ujigami to Ujiko [Ujigami and Ujiko]. In A. Fukuda \& N. Miyata (eds.), Nihon minzokugaku gairon [Introduction to Japanese Folklore] (in Japanese, pp. 159-169). Tokyo: Yoshikawakōbunkan.

Komatsu, K. (1999a). Hakamairi [Visitting grave]. In A. Fukuda et al. (eds), Nihon minzoku daijiten ge [Dictionary of Japanese folklore Volume 2] (in Japanese, pp. 345-346). Tokyo: Yoshikawakōbunkan.

Komatsu, K. (1999b). Tsuizen kuyou [memorial service for ancestors]. In A. Fukuda et al. (eds.), Nihon minzoku daijiten ge [Dictionary of Japanese folklore Volume 2] (in Japanese, pp. 116-117). Tokyo: Yoshikawakōbunkan.

Matanle, P. (2010). Introduction: A special focus on shrinking regions. Social Science Japan Journal, 13(2), 183-185. http://doi.org/10.1093/ssjj/jyq064 
Matsuzaki, K. (1989). Konoyo [Konoyo]. In H. Torigoe (Eds.), Minzokugaku wo manabu hito notameni [For students of Japanese folklore] (in Japanese, pp. 189-209). Kyoto: Sekaishisosya.

Naikakufu [Cabinet Office, Government of Japan]. (2014). Köre-shakai hakusho (Annual report on the aging society). Retrieved April 1, 2015, from http:/www8.cao.go.jp/kourei/whitepaper/w-2014/zenbun/s1_1_5.html

Nakagome, M. (1999). Ie [Ie: Japanese traditional family]. In A. Fukuda et al. (eds.), Nihon minzoku daijiten jō [Dictionary of Japanese folklore Volume 1] (in Japanese, pp. 62-64). Tokyo: Yoshikawakōbunkan.

Odagiri T. (2006). Chusankan chiiki no jittai to seisaku no tenkai [Current status of hilly and mountainous areas and related Policy]. In Y. Yaguchi (eds.), Chusankan chiiki no kyōsei nōgyo system [Coexistence agricultural system in hilly and mountainous area] (in Japanese, pp. 1-15). Tokyo: Nōrintōkeikyōkai.

Ohno, A. (1991). Gendai sanson no kōreika to genkai shūraku [Aging and boundary community in contemporary mountain village]. Keizai [Economy] (in Japanese), 1991 July, 55-71.

Ohno, A. (2005). Sanson kankyō shakaigaku josetsu [Introduction of environmental sociology in mountain village] (in Japanese). Tokyo:Nōsangyosonbunkakyōkai.

Okubo, M., Tanaka, M., \& Inoue, M. (2011). Matsuri wo toshite mita tashutsusya to shusshinson tono kakawari no henyou: Yamanashi ken Hayakawacho Mogura shuraku no baai [Changes in relationships between out-migrants and their origin village:focusing on traditional festivals in Mogura village, Hayakawa town, Yamanashi prefecture, Japan]. Sonraku shakai kenkyu journal [Journal of rural studies] (in Japanese), 17(2), 6-17. http://doi.org/10.9747/jars.17.2_6

Oikawa, K. (2007). Yama no mura kara: Rekishi bto minzoku no tenkai [From a mountain village: History and folk in transition] (in Japanese). Tokyo : Kindaibungeisha.

Somusho Tōkeikyoku [Statistics Bureau, Ministry of internal affairs and communications]. (2012). Jinkou gensyo shakai gannen ha itsuka? (When population decline has started?), Tōkei Today No.9., Retrieved June 3, 2015, from http://www.stat.go.jp/info/today/009.htm

Sonoda M. (1999a). Ujigami [Ujigami]. In A. Fukuda et al. (eds.), Nihon minzoku daijiten jō [Dictionary of Japanese folklore Volume 1] (in Japanese, pp. 158-159). Tokyo: Yoshikawakōbunkan.

Sonoda M. (1999b). Jinja [Shrine], In A. Fukuda et al. (eds.), Nihon minzoku daijiten jō [Dictionary of Japanese folklore Volume 1] (in Japanese, pp. 883). Tokyo: Yoshikawakōbunkan.

Suzuki, E. (1968). Suzuki Eitarō chosakushū I [Suzuki Eitarō collection 1] (in Japanese). Tokyo: Miraisha.

Tachibana S., Inoue, M., Yasumura, N., Okuda, H., Yamamoto, N., \& Kuboyama, H. (1998). Jinteki tsunagarikara mita shutoken kinko sanson no genjo to tenbo: Saitamaken Otakimura wo jireini [Current State and Prospect of Mountain Villages Near the Metropolitan Area through Their Human Networks : A Case Study of Otaki Village]. Ringyokeizaikenkyu [Journal of forest economics] (in Japanese), 44(2), 67-72.

Torigoe, H. (1993). Ie to Mura no shakaigaku [Sociology of ie and mura] (in Japanese). Tokyo: Sekaishisosha.

Torigoe, H. (1994). Chiikijichikai no kenkyū [Research about local community associations] (in Japanese). Kyoto: Minerva shobō.

Tokuno, S. (2008). Nosanson shinko ni okeru toshi noson koryu: Green tourism no genkai to kanousei: Seisaku to Jittai no hazama de [Urban and rural interchanges on rural promotion: feasibilities and limitations of green tourism within social policies and actual circumstances]. Nenpo sonrakushakaikenkyu [Annual bulletin of rural studies] (in Japanese), 43, 43-93.

Uranishi T. (1987). Jinja saishi. In K. Ueno et al. (eds.), Shinban minzoku chōsa handbook [Folklore study handbook new edition] (in Japanese, pp.134-142). Tokyo:Yoshikawakōbunkan.

\section{Copyrights}

Copyright for this article is retained by the author(s), with first publication rights granted to the journal.

This is an open-access article distributed under the terms and conditions of the Creative Commons Attribution license (http://creativecommons.org/licenses/by/3.0/). 